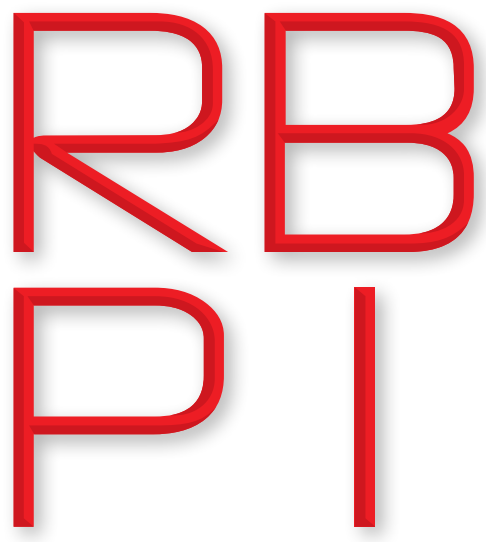

Revista Brasileira de Política Internacional ISSN 1983-3121

http://www.scielo.br/rbpi

\section{Marcos Tourinho}

Fundação Getúlio Vargas, Centro de Relações Internacionais. São Paulo - SP, Brazil (marcos.tourinho@fgv.br).

iD ORCID ID: orcid.org/0000-0002-3600-3815

\section{Copyright:}

- This is an open-access article distributed under the terms of a Creative Commons Attribution License, which permits unrestricted use, distribution, and reproduction in any medium, provided that the original author and source are credited.

- Este é um artigo publicado em acesso aberto e distribuído sob os termos da Licença de Atribuição Creative Commons, que permite uso irrestrito, distribuição e reprodução em qualquer meio, desde que o autor e a fonte originais sejam creditados.

\title{
Brazil in the global anticorruption regime
}

DOI: http://dx.doi.org/10.1590/0034-7329201800104

Rev. Bras. Polít. Int., 61(1): e004, 2018

\section{Abstract}

Brazilian anticorruption law and institutions were significantly transformed in recent decades. This article traces those transformations and explains how the international anticorruption and money laundering regimes contributed to their development. It argues that those international regimes were internalised in the Brazilian system through three mechanisms: inspiration and legitimation, coercion, and implementation support, and were critical to the transformation of Brazilian institutions.

Keywords: Brazil, anticorruption, money-laundering, global governance.

Received: April 28, 2017

Accepted: October 23, 2017

\section{Introduction}

Tn 2014, a major corruption investigation engulfed Brazil 1 as it uncovered a series of bribery and campaign financing schemes involving several of the country's largest companies and numerous politicians from across the political spectrum. The multi-year Lava-Jato ("Car-Wash") operation has been exceptional in its magnitude. Operations so far have accounted for US\$15 billion in fines and assets recovery and almost 1,400 years in prison sentences. Over 50 high-ranking politicians are currently being investigated, and plea bargain testimonies have mentioned or implicated all presidents of Brazil since democratisation, the heads of both houses of parliament, and numerous state governors and ministers.

Like many major corruption schemes, Brazil's was in many ways fundamentally transnational. The uncovered facts so far directly involve 14 countries, with implications for former or current heads of states of Argentina, Chile, Colombia, the Dominican Republic, Ecuador, Guatemala, Mexico, Panama, Peru, and Venezuela (BBC-Brasil 2017). Odebrecht alone paid almost US\$ 800 million in bribes abroad. As a result, investigations have thus far involved 44 jurisdictions (Giacomet Junior and 
Silveira 2017) and agreements are simultaneously being negotiated (or have been reached) in several states, most notably the United States and Switzerland ${ }^{1}$.

The background for these discoveries is constituted by a major increase in the capacity of Brazilian institutions to fight corruption. After decades of relative impunity in relation to corruption and other white-collar crimes, there has been a deep transformation in the way the country's institutions address deviance taking place in the higher ranks of power. Albeit imperfectly (and still incompletely), state control institutions have been able to investigate and effectively prosecute sitting officials and others in positions of power. Large private companies which were previously considered beyond the law were punished and forced to change their approach. What is behind Brazil's substantial anticorruption capacity building?

This article contends that a critical but often overlooked factor was the fast-paced evolution of the global anticorruption and anti-money laundering regimes throughout the 1990s and 2000s. While there is much to be said about endogenous institutional transformations that facilitated institutional change (Praça and Taylor 2014), this article specifically emphasises the country's engagement with international regimes and the transformations it produced in domestic anticorruption policy. It is clear, however, that both streams - domestic and international - developed intertwined, and their distinction serves primarily for analytical purposes.

The article emphasises how new norms and practices emerging globally were internalised in the Brazilian laws and institutions and, combined with endogenous developments in state institutions, produced a more robust anticorruption and money laundering system. The argument unfolds in three steps.

First, it traces the establishment and transformation of the global anticorruption and antimoney laundering regimes. It explains how and why new norms and institutions were developed in the course of over two decades to produce a relatively robust transnational regime involving dozens of institutions, international treaties, domestic legislation, and policy networks. This dual regime, which involves public and private, domestic, and international actors, is then characterised on the basis of the principal functions of international governance.

Second, the article explores the mechanisms through which those global norms and institutional practices were internalised in the Brazilian anticorruption system. There were three principal mechanisms: inspiration and legitimation, coercion, and implementation support. The section emphasises the process by which a global legal harmonisation in the areas of corruption and money laundering took place, how international cooperation became a critical factor to dismantle transnational crime, and details their impacts in Brazil.

1 The total number as of March 28, 2017 includes both passive and active cooperation: Andorra, Antigua and Barbuda, Argentina, Austria, Bahamas, Canada, Cayman Islands, Chile, China, Colombia, Curaçao, Costa Rica, Denmark, Dominican Republic, Ecuador, France, Germany, Gibraltar, Guatemala, Hong Kong, Isle of Man, Italy, Israel, Japan, Liechtenstein, Luxemburg, Macau, Mexico, Monaco, Netherlands, Norway, Panama, Peru, Portugal, Russia, Singapore, South Korea,Spain, Sweden, Switzerland, United Kingdom, United States, Uruguay and Venezuela. 
Lastly, the article concludes with an argument about the continued influence of global normative transformations in the analysis of domestic political change. It specifies the influence of global anticorruption and money laundering regimes in Brazil's anticorruption policies and argues that it is impossible to interpret the country's domestic policies in this area without reference to those international norms and institutions.

\section{The global governance of corruption and money laundering}

The issues of corruption and money laundering are relatively new within the international relations agenda (Wang and Rosenau 2001). Through much of the twentieth century, corruption was largely understood to be inherent to international investment and development (Huntington 2006), and it was only in the late 1980s that global money laundering regulation began to emerge. By the early 2000s, the situation had significantly changed and a robust international anticorruption regime was in place - involving a large number of international treaties, national laws with extraterritorial reach, public and private regulatory systems, and public and private, national and international institutions.

Corruption issues entered the global political agenda slowly. A starting point was the passing of the 1977 Foreign Corrupt Practices Act (FCPA) in the United States. The law was approved following the scandals of Watergate, as it became clear to the public that US companies widely used foreign slush funds in the United States (Heimann 1997). The FCPA is a law of extraterritorial application that criminalises and punishes US and foreign companies and executives who, while associated with the US market, pay bribes and advantages to obtain influence abroad. Its extraterritorial enforcement has been central to the legislation, both in terms of its reach as well as its capacity to influence the international regulatory environment. Thus, although the enforcement of the FCPA was relatively lax for decades (Windsor and Getz 2000), it did serve as a model to the anticorruption initiatives that followed.

Yet, for much of the 1980s and 1990s, corruption remained central to the business strategies of multinational companies, often with the tacit approval of their respective states. In countries like Canada, France, Japan, and Germany, for example, it was still possible as of the late 1990s to deduct tax over bribes paid abroad, as long as the identity of the recipient and a proper business reason were provided (Windsor and Getz 2000). Transformation emerged during the 1990s, as two parallel processes contributed to an increase in the depth and density of the international anticorruption regime: the agenda of international organisations and the anti-money laundering (AML) policies motivated by counter-drug traffic and terrorism policies.

The end of the cold war introduced a new emphasis of themes related to domestic governance in international institutions such as the World Bank and the International Monetary Fund (IMF), among others (Wang and Rosenau 2001). Those organisations, partly motivated by donor concerns, began to interpret corruption as central to approximating the development trajectories of northern 
and southern countries. While some considered that premise to be questionable (Kennedy 1999; Bukovansky 2006), those organisations produced a new wave of research and technical notes seeking to improve the management of public resources, including administrative procedures, to establish business-friendly regulatory environments (for the IMF) and to overcome obstacles to social and economic development (World Bank). This change in perspective was heavily influenced by Transparency International, a transnational nongovernmental organizations (NGO) founded in 1993 which successfully contributed to defining and framing the problem of corruption as a problem within the global agenda (Wang and Rosenau 2001).

Transformations in the international anticorruption regime were also motivated by a desire from the United States to level the playing field in an increasingly competitive global economy. Concerned about potential commercial disadvantages for US companies due to the FCPA, the country promoted the internationalisation of its domestic anticorruption legislation (Windsor and Getz 2000; Bukovansky 2006, Rose 2015). The strategy was two-fold: first, to encourage the establishment of international anticorruption treaties and conventions; second, to strengthen the extraterritorial enforcement of its own law. These strategies were successful in encouraging other states to take a similar path in addressing corruption issues by their own companies or in their territories.

Those various streams of agenda-setting and norm-making laid the groundwork for a series of international anticorruption treaties and conventions, helping to shape the regime.

In 1996, the Organization of American States (OAS) sponsored the establishment of the InterAmerican Convention against Corruption, the Caracas Convention, a document designed to strengthen domestic institutions that contribute to preventing, identifying, punishing, and eradicating corruption. To that end, the Inter-American Convention promoted the criminalization of certain activities associated with corruption and facilitated international cooperation among the parties on legal assistance and technical cooperation, extradition, and the tracing and freezing of assets (Manfroni and Werksman 2003). In 2001, an influential mechanism for assessing compliance by party-states, Mechanism for Follow-Up on the Implementation of the Inter-American Convention against Corruption (MESICIC), was established (Guerzovich 2011). Brazil enacted the convention in 2002, with decree 4.410/2002.

Roughly at the same time, the Organisation for Economic Co-operation and Development (OECD) was undergoing work on what in 1997 became the Convention on Combating Bribery of Foreign Public Officials in International Business Transactions, which, following the FCPA model (Spahn 2013), sought the criminalisation of bribery paid to foreign public officials (George et al. 2000). The Convention, also open to non-OECD members, establishes clearer accounting and auditing rules and explicitly prohibits income tax deductions for bribe payments, a then still common practice. The convention followed aspects of the format developed in the OAS and remains influential, notably among industrialised countries. Brazil internalised the convention with decree 3.678 (Brasil 2000).

In 2000, the United Nations General Assembly established an ad-hoc committee to work on the United Nations Convention against Corruption (UNCAC), signed in Merida in 2003. The text consolidated the various regional initiatives and became the principal and most comprehensive 
international instrument on the topic. The Convention is organized in five main areas: prevention, criminalization and law enforcement, international cooperation, asset recovery and technical assistance, and information exchange. In 2009, a formal implementation review mechanism (IRM) with a selfassessment checklist was established. Brazil enacted the Convention in 2006, with decree 5.687 (Brasil, 2006). The United Nations also sponsored the United Nations Convention against Transnational Organized Crime, signed in Palermo, which notably defined the criminal offense of participating in an organised criminal group, and endorsed the use of special investigation techniques such as plea bargains. The Convention also had a catalytic role in international cooperation by providing a more robust formal basis for mutual legal assistance, extradition and law enforcement cooperation. The Convention entered into force in 2003, and Brazil enacted it with decree 5.015 (Brasil 2004).

In parallel to those developments in the anticorruption regime, the 1990s and 2000s saw the emergence of a robust anti-money laundering (AML) regime, which had major impacts on anti-corruption policies. Money laundering is the process of hiding the illicit origin of funds derived from criminal activities. It is itself a crime motivated by the need to legitimize and reintroduce large amounts of capital into the financial system without warning governing authorities. Thus, anti-money laundering policies seek to hinder the use of such funds by criminals, further increasing costs and decreasing the attractiveness of crime (Sharman and Chaikin 2009).

The AML regime was initially motivated by a widespread concern in the late 1980s with drug-related assets seizure and forfeiture. Governments worldwide adopted initiatives to enable the control of those assets and committed themselves to international cooperation within the area. The 1988 United Nations Convention Against Illicit Traffic in Narcotic Drugs and Psychotropic Substances (1988 Vienna Convention) (United Nations 1988) was crucial in this process, as it mandated extensive cooperation and established more robust legal authority for the various law enforcement-related tasks, including mutual legal assistance and the seizure of assets. In the United States, the 1988 Kerry Amendment to the Anti-Drug Abuse Act enabled the US government to cut foreigners off the US financial and clearing systems if they didn't follow specific standards of money laundering control (Andreas and Nadelmann 2006).

Still in the 1980s, the Basel Committee on Banking Supervision (BCBS), a part of the Bank for International Settlements (BIS), began to publish norms and recommendations for best practices in monitoring the financial market, emphasising the issue of money laundering (Marcussen 2007). Although it does not have a legally binding character, the Basel Committee guidelines have a powerful normative impact and are adopted globally. Those recommendations were important in the drastic increase in obligations facing banks and regulatory authorities in the supervision of financial markets. The greater transparency provoked by the strengthening of the monitoring of capital flows was crucial to the transformation that later dismantled the acceptability of absolute bank secrecy.

The 1990s saw the creation or enhancement of national Financial Intelligence Units (FIUs) worldwide. Those bodies, in Brazil's case COAF, are responsible for monitoring the financial system for unusual or suspect activities. The Egmont Group, created in 1995, is an informal global network 
of those national bodies. The 152-members institution established new paths for international exchange and cooperation through the promotion of best practices in anti-money laundering and financial intelligence, training and capacity building, and safer information sharing mechanisms.

Those initiatives were foundational to the strengthening of anti-money laundering policies worldwide throughout the 1990s and 2000s. This multifaceted effort is most visible in the form of the Financial Action Taskforce (FATF) by the G7 in 1989. The idea was to establish a transnational network of governmental treasury officials from industrialized countries to coordinate anti-money laundering policies, especially funds originating from drug dealing. Today, FATF has 34 member states, including all BRICS countries. In 1990, it developed 40 recommendations on how to handle the problem of money laundering, which were updated several times and remain the central norm in the field. Although the recommendations are not mandatory and FATF insists it has no interest in creating new legal obligations, in practice they have become binding. This is because although FATF has a limited number of member countries, it forcefully seeks universal adherence through monitoring and blacklisting, creating new problems from the point of view of consent in international law (Sharman 2011; Krisch 2014; Rodiles 2017).

This was particularly the case since September 11, 2001, when the fight against (the financing of) terrorism generated a new sense of urgency in attempts to make the international financial system more regulated and transparent. The additional recommendations made by FATF after the attacks in New York and Washington D.C. added to the new impetus with which the U.S. Treasury Department began to demand compliance with those standards. Lack of compliance would often result in public and private entities being excluded from the U.S. market (Andreas and Nadelmann 2006; Biersteker and Eckert 2007).

As a result, efforts to counter the financing of terrorism (CFT) have had a major impact on anti-money laundering policies more broadly. New demands imposed on the markets resulted in far greater transparency and monitoring of the international financial system across the board, often through questionable means (Köppel 2011). Since then, in practice, absolute bank secrecy ceased to be the rule and financial institutions are obliged to collect and share information about their account holders with governments. Since then, there has been an immense growth in information sharing and international cooperation in the area, often led by the then recently established Financial Intelligence Units (FIUs). These transformations have facilitated the monitoring of individuals associated with terrorism financing, but also in cases of money laundering, corruption, tax evasion, and the regular monitoring of politically exposed persons more broadly.

The dual anti-corruption/money laundering Anti-corruption/Anti-Money Laundering (AC/AML) regime is composed by a robust system of national and international law, norms and institutions. First, there are obligations established by international treaties. Second, there are the national laws with extraterritorial effect (such as FCPA in the United States and the Bribery Act in the United Kingdom, among others), due to the presence of companies and financial institutions in the markets of those countries. Third, there are international norms that, considered imperative by market agents, have been applied by both the private and public sectors independently of legal 
obligation. Finally, there are formal and informal networks of regulators cooperating systematically through dedicated international fora, such as FATF and the Egmont Group.

The global governance of corruption thus takes place around those bodies and their relationship with domestic institutions worldwide. Combined, they perform the central functions of global governance in the field: setting the agenda and creating issues, rule-making, implementation and enforcement, and monitoring and evaluation (Avant et al. 2010). Table 1 summarises the principal actors and functions in international anticorruption and anti-money laundering governance.

\section{Table 1. Principal actors and functions of international anticorruption/money laundering governance}

\begin{tabular}{lll}
\hline Global governance functions & \multicolumn{1}{c}{ Anti-corruption actors } & Anti-money laundering actors \\
\hline Agenda setting and creating issues & $\begin{array}{l}\text { Transparency International, IMF, } \\
\text { World Bank, United States }\end{array}$ & $\begin{array}{l}\text { FATF, UN Security Council, } \\
\text { United States }\end{array}$ \\
Making rules & $\begin{array}{l}\text { UNCAC, OECD, OAS, national } \\
\text { legislators, BCBS }\end{array}$ & $\begin{array}{l}\text { United States, FATF (and regional } \\
\text { bodies), national legislators, Council } \\
\text { of Europe, UN Security Council }\end{array}$ \\
Implementation and enforcement & $\begin{array}{l}\text { Domestic legislators, regulators, } \\
\text { police, prosecutors. }\end{array}$ & $\begin{array}{l}\text { Financial institutions, dealers of } \\
\text { valuable goods, Financial Intelligence } \\
\text { Units, INTERPOL, FATF }\end{array}$ \\
& $\begin{array}{l}\text { MESICIC, OECD, United Nations } \\
\text { Office on Drugs and Crime } \\
\text { Evaluation and monitoring }\end{array}$ & FATF, Egmont Group, UNODC, \\
& & \\
\hline
\end{tabular}

Source: Prepared by the author (2017).

With the gradual establishment of this regime, the implementation of anticorruption norms became far more robust worldwide. Due to the development of anti-money laundering norms and institutions (motivated by drug trafficking and counterterrorism), the international financial system has become far more transparent, and bank secrecy shifted from being an acceptable norm to a risky exception - significantly affecting anticorruption policies worldwide. There has been a substantial increase in the number of domestic laws of extraterritorial reach, as well as in the intensity of their implementation and levels of punishment (David-Barrett 2014). This period also saw great worldwide legislative harmonisation and a drastic increase in international cooperation for both financial intelligence and in criminal-administrative procedures, enabling improved evidence-sharing procedures as well as assets recovery.

Those worldwide transformations were central to the upsurge in anticorruption law enforcement in Brazil. Between the late 1990s and early 2010s, substantial improvements were made to laws and institutions which increased their effectiveness against corruption. The next section describes the processes through which Brazilian state institutions appropriated and operationalized the international regime in the country. 


\section{Three modes of internalization}

The internalisation or global anticorruption norms in Brazil is the result of both endogenous and exogenous processes. It is certainly the case that an element of worldwide norm emergence and cascade (Finnemore and Sikkink 1998) took place in the decades described above. The polycentric impulse towards renewed anticorruption policies was robust and able to influence the agendas of multiple states. In the area of money-laundering, international institutions were at the forefront of addressing the problem of transnational crime by promoting model legislation, closely monitoring the implementation of commitments and imposing penalties on those that lagged behind. In the case of the anticorruption/money laundering regime, it is clear several international norms and institutions were designed with the deliberate purpose of influencing domestic legal systems (Rose 2015).

Yet, one must also emphasise the extent to which portions of the Brazilian bureaucracy took advantage of global normative opportunities to accomplish domestic objectives. Local agents participate in the norm-making process by actively selecting, borrowing, and modifying global norms and institutions to fit their worldviews and interests (Acharya 2004).

In Brazil, an important mechanism for bureaucratic activism was the National Strategy Against Corruption and Money Laundering (ENCCLA), an inter-ministerial forum established in 2002 to coordinate policy on those issues. The network-like body deliberated legislative change, provided government-wide legitimacy for specific initiatives and became a centre of thought leadership in those areas. The institution worked as a catalyser of initiatives related to corruption and money laundering, establishing guidelines, adjusting administrative and criminal prosecution practices as well as promoting key legislation, such as the country's $3^{\text {rd }}$ generation AML law (12.683) (Brasil 2012). As the centre for government-wide debate and decision-making within the area, ENCCLA contributed to a substantial transformation of Brazilian AC/AML norms and institutions (Araujo 2012).

What follows characterises the three modes of internalisation of global anticorruption norms in Brazil.

\section{Inspiration and legitimation}

The first mode, inspiration and legitimation, takes place when international treaties, or domestic laws of third countries serve as an inspiration or legitimator for the reformulation of domestic laws and institutional practices. Brazil takes part in all main international anticorruption and anti-money laundering mechanisms, discussed above. Those instruments, typically associated with international organisations, played a crucial role in sophisticating the country's institutional apparatus in those areas, notably in technical fields off the radar of public opinion and, often, political parties. 
International treaties and foreign legislation offer models and best practices to those interested in advancing domestic anti-corruption mechanisms. In Brazil, the establishment and later improvement of anti-money laundering legislation, for example, was directly influenced by the Vienna, Caracas, and Palermo conventions, among other international instruments. Similarly, the Brazilian approach to plea bargains was inspired by similar practices in Italy and the United States. The validation of those (and other special investigation techniques) in the UN Convention against Organised Crime (Palermo) legitimised the practice and encouraged Brazil's implementation of the mechanism.

This validation matters because laws and institutional forms emerging from international treaties are often understood as being inherently legitimate. International treaties and their associated institutions such as the United Nations are repositories of legitimacy (Hurrell 2010), which provides them with a certain gravitas that facilitates their domestic implementation. Domestic actors seeking institutional change thus operationalize that legitimacy to push for new laws and practices which, while having emerged abroad, suit their worldviews and interests.

International treaties also serve as reputational intermediaries, that is they enable different parties to signal an intent to adopt a norm or address an issue. This explains why non-compliant states join anticorruption mechanisms (David-Barrett and Okamura 2013). The OAS and OECD Conventions, for instance, committed the country to establishing a domestic anticorruption law. Once such pledge is made, it became easier for domestic actors favourable to their implementation to operationalize international legitimacy to leverage their positions. In the case of Brazil, within the Ministry of Transparency (formerly Controladoria-Geral da União (CGU)), its Secretariat for Transparency and Corruption Prevention (STCP) is formally responsible for following the implementation of Brazil's international anticorruption commitments.

As a result, treaty commitments are often framed by domestic actors as unfulfilled promises, and serve as an informal agenda for institutional change. In Brazil, the Federal Prosecution Service (Ministério Público Federal (MPF)) spearheaded a campaign for new anticorruption laws that explicitly used treaty commitments and the legislation of third countries as a legitimising factor. Refuting critiques to their proposal, Rodrigo Janot, Brazil's Prosecutor General, stated: “None of these measures constitute jabuticaba [a native Brazilian fruit], none are a Brazilian invention. These are all instruments which are either present in international treaties or in the domestic systems of countries that serve as a paradigm for the evolution of the Brazilian State" (Pontes 2016, our translation).

\section{Coercion}

The second mechanism, coercion, occurs when sections of the public or private sectors are implicitly or explicitly obliged to transform practices or regulations to be in compliance with imposed formal or informal international standards or practices. Coercion may take place with 
different levels of consent and, in some cases, may even be welcomed by portions of the state or private sector, as external coercion may still benefit their particular views or purposes.

Monitoring and peer-review mechanisms, for example, are a typical form of "consented coercion". International anticorruption treaties have included peer-review or monitoring implementation mechanisms, such as OAS's MESICIC, UNCAC's IRM and OECD Working Group on Bribery, which push state parties to institutional change. In those mechanisms, signatory states regularly submit an account of their anticorruption or money laundering policies, which are then evaluated by peers on the basis of that and additional information. The mechanisms then produce evaluation reports and recommendations for furthering anticorruption systems, seeking both technical and political impacts (Guerzovich 2011). Those instruments rely typically on relatively low-level but regular pressure, normative learning and legalisation to take a gradualist approach to international cooperation and political change (Abbott and Snidal 2002). Beyond facilitating state-to-state cooperation and exchange, monitoring mechanisms have been able to shape domestic anticorruption policy and approximate them to the relevant international standards.

A more robust, or less consented form of coercion takes places in the field of antimoney laundering, with significant consequences to anticorruption policy. In addition to the mechanisms described above, FATF developed a robust system of monitoring and evaluation of the implementation of its recommendations, which includes a peer-review mechanism, FATF-style regional bodies such as Grupo de Acción Financiera de Latinoamerica (GAFILAT) and a blacklist of those considered to be high-risk jurisdictions. The system was motivated by a view that antimoney laundering systems are only as strong as their weakest link, as the efforts of compliant states could be undermined or even made counterproductive if those standards led to capital flight to noncompliant states.

FATF has had two blacklisting systems. First, a list of Non-Cooperative Countries and Territories (NCCT) was in place between 2000 and 2002, and second through the International Cooperation Review Group (ICRG) since 2006. In both cases, lists were established to create pressure to comply by a system of naming and shaming which damage the reputation of listed countries and impair their participation in the international financial system (Sharman 2011; Nance 2015). As Sharman (2011) described,

[...] criteria for listing included such matters as the failure to criminalize money laundering, failure to extend international cooperation in the fight against money laundering, posing a substantial money-laundering threat, failure to join a regional AML body, and the refusal to publish IMF financial sector reports (despite the IMF's insistence that publication was entirely voluntary and depended on the consent of the government assessed) (105).

Being listed as a non-cooperative jurisdiction has significant consequences. The list deliberately undermines confidence in said jurisdictions and foster distrust in their institutions. FATF members 
and non-members are obliged under Recommendation 21 to exercise enhanced vigilance in dealings with supposedly non-cooperative countries. While being listed by FATF does not create any formal international legal obligations or sanctions, the reputational damage noncompliance causes is reverberated as other states, international organisations and private firms issue red flag warnings and adjust their policies.

Those consequences are further enhanced in the course of private sector implementation. Listed countries and their firms are subject to enhanced vigilance by financial sector institutions, and are often included in informal blacklists of financial institutions and anti-money laundering software. Often, financial services firms choose to withdraw entirely from listed jurisdictions, fearing the reputational and commercial costs of being associated with risky financial systems. Those practices harm their capacity to participate in the world economy, slowing and increasing the costs of wire transfers and correspondent banking, which affects not only financial institutions but all merchants, industries, and investments (Sharman 2011). This coercive system is enhanced further by bilateral state pressure. Most notably, the United States has explicitly threatened (and at times imposed) cutting foreign governments and firms off the US financial system for noncompliance with some principles of anti-money laundering policy.

As a result, from the perspective of policymakers, being blacklisted by FATF is a serious problem. This has had impacts far beyond listed jurisdictions, since blacklisting was deliberately employed as a warning to others - to push the entire system towards compliance. In several third countries policymakers rushed to adjust their legislations to avoid being listed. While Brazil was never in serious risk of blacklisting, the coercive nature of the anti-money laundering regime repeatedly pushed Brazilian legislation and institutions forward and, most recently, provoked a government-wide initiative to criminalise the financing of terrorism.

Finally, from the standpoint of the Brazilian private sector, coercion was also the principal mechanism through which it entered the global anticorruption regime. This coercion has a dual source. First, Brazilian companies are subject to other, foreign systems of anticorruption governance. In the international financial system, Brazilian companies became more exposed due to the increase in surveillance of international financial transactions; notably since the enactment of the PATRIOT Act in the United States. There have also been growing demands caused by foreign investment and the globalisation of production chains, as partners increasingly demand background checks and due diligence investigations (DiBianco and Pearson 2008). Second, for companies for whom corruption is essentially a business model (Sidhu 2009), the tension between non-compliance and the law takes place simultaneously in multiple criminal justice systems. Brazilian firms are subject to Brazilian and foreign laws with extraterritorial reach, making both corruption and anticorruption policies transnational in practice. Moreover, the reiterated interaction between a firm and (criminal or administrative) regulatory systems has harmed access to contracts, credit, and investment, threatening the economic viability and very existence of those companies.

As a result, in Brazil as much as elsewhere, the strengthening of domestic laws and institutions provoked the expansion and deepening of private sector compliance programmes. The personal 
vulnerability of executives to heavy fines and prison sentences pushed some companies away from illicit business models to set systems of internal regulations and control. Those programmes serve to protect the companies (and its employees) from criminal risk, as much as to improve their standing in potential non/deferred prosecution or plea agreements, and to qualify them to the credit necessary to ensure their economic viability.

\section{Implementation support}

The third mode of internalisation, implementation support, takes place when international norms and institutions transform domestic practices at the operational level, either by improving or facilitating the performance of domestic institutions. The forces behind those transformations may have structural or contextual origins.

For instance, the emergence and quasi-universalization of anti-money laundering norms in the 1990s and 2000s provoked structural transformations in the international financial system. Gradually, banking secrecy and anonymity became normatively unacceptable. New mechanisms of information sharing and financial intelligence between countries were developed and techniques for tracing funds and obtaining evidence of corruption and money laundering in third countries was greatly improved. Once law enforcement officials realised that the same normative models techniques, through which they analysed suspected bank transfers for the countering of terrorism, could be used for other crimes such as corruption and tax evasion, new avenues for law enforcement were opened.

This was further enhanced by a dramatic increase in international cooperation on criminal issues, a process that has been central to anticorruption policies worldwide. In recent decades, numerous international cooperation agreements in both criminal and administrative levels were established, joining the various formal and informal cooperation mechanisms between technical bodies.

This increase in the scope and density of international criminal cooperation followed, in many ways, the internationalisation of crime itself. Having historically taken advantage of "transnational" or "extraterritorial" domains to engage in proscribed activities, criminal organisations pioneered techniques to benefit from a lack of coordination between states to hide or profit from crime. Much like criminals began to use advanced communications and transportation technologies to engage in their activities, so did policing and prosecution services. Authorities began to operate in a more connected manner not only in the investigation phases, but also in prosecution and execution of judicial decisions.

Two structural factors were crucial in this development. First, there has been a substitution from the traditional means of international judicial cooperation - from diplomacy and letters rogatory towards simplified mutual legal assistance mechanisms. In the new model of cooperation, inaugurated multilaterally by the 1965 Hague Service Convention, central authorities - normally of a specialised and technical character - began to centralise the execution of cooperation, avoiding 
lengthy diplomatic procedures, the duplicity of work and effectively accelerating cooperation procedures. Notably since the 1988 Vienna Convention, there has been a transition in which criminal cooperation was previously understood as a "courtesy" from one country to the other to an interpretation of collaboration and obligation of principle, a legal commitment (Trotta and Ferreira 2013).

Second, there has been a substantial increase in the levels of global harmonisation of criminal law in the area, largely due to the effectiveness of the above-mentioned norms and institutions, simplifying the interpretation and execution of cooperation demands. Technical training, offered either bilaterally or by the UNODC, helped to produce a transnational anticorruption enforcement network that can engage on the basis of common grounds. By offering a unified legal foundation for cooperation, major multilateral conventions became powerful facilitators of international cooperation. Even if they imply major commitments with domestic normative change, those agreements have been able to attract a large number of signatory States, emerging from a wide variety of legal systems.

Thus, a favourable environment emerged to enhance cooperation between states on anticorruption issues. Beyond major treaties, a large number of bilateral and multilateral mutual legal assistance agreements, among others, have simplified cooperation efforts (Aras 2016). In the last decade, informal transnational networks of law enforcement officials emerged, facilitating communication and collaboration on specific cases. Often, those officials engage as scholarspractitioners in international conferences and professional associations.

These have allowed for a more speedy and intense exchange of information and experiences that sophisticated international cooperation. International joint investigation teams and formal attachés from prosecution services, for example, are relatively recent mechanisms that enhance law enforcement cooperation and facilitate pre-trial investigation and evidence gathering, assets freeze, and recovery as well as extradition in corruption cases.

Brazil has benefited greatly from those new mechanisms, which have helped to transform domestic anticorruption norms and institutions. The transnational enforcement of anticorruption laws has become an unavoidable tendency, one in which Brazil enthusiastically takes part. The country currently administers 4.000 cooperation processes, 3.700 of which were requested since 2015 (Giacomet Junior and Silveira 2017). The "Lava-Jato" operation alone involved thus far over 200 international cooperation procedures, constituting one of the central operational pillars of the investigations.

The move towards closer forms of cooperation continues to evolve in a fast pace. In 2017, Brazil and 10 other Latin American states published a declaration committing themselves to enhancing formal and informal cooperation on anticorruption issues (MPF 2017). Roughly at the same time, an unprecedented joint taskforce was established among 15 Latin American states to investigate a single scheme, that was uncovered by "Lava-Jato" in Brazil (Benites 2017). While those initiatives may suffer from political obstacles, they may also serve to kickstart a more systematic, quotidian engagement between law enforcement officials in the region for anticorruption purposes. 


\section{Conclusion: global normative transformation and domestic political change}

The last twenty years saw a profound transformation in Brazilian anticorruption law and institutions. This transformation is the result of both endogenous and exogenous processes. Among those conceived domestically, one could emphasise the gradual reconstitution of the Prosecution Service (Ministério Público) from the 1988 Constitution (Kerche 2010), and the constitutional amendment \#35, which enabled the prosecution of sitting officials without the approval of their respective legislative bodies. Other factors (which also involved local appropriation and adaptation) were more influenced by the evolving international normative context.

This article emphasised the processes through which the global governance of corruption gained a notable influence in the formulation and transformation of Brazilian laws and institutions. All of the three most important legislations enabling a greater effectiveness of anticorruption prosecution, the anti-money laundering (2012), anticorruption (2013) and organised crime (2013) laws, were deeply influenced by foreign laws or international treaties. Essential investigation and prosecution methods such as plea bargains and agreements, sophisticated tracing of assets and the use of software for treating large amounts of financial data have been either enabled or influenced by processes taking place globally.

It is certainly the case that the global anticorruption and money laundering regimes are not a panacea. As this article emphasised, both have been developed from altruistic as well as self-interested motivations and often used dubious methods to reach current levels of compliance. These different motivations, such as levelling the international market's playing field, strengthening fundamental rights and democratisation or managing global security threats (Guerzovich 2011), are differently emphasised depending on the time and institutional context in which these initiatives take place. In the case of money laundering, the deeply coercive methods used to achieve compliance generate serious problems from the perspective of consent in international law and highlight the deeply hierarchical character of even the most "liberal" aspects of international order.

Often, it was exactly the 'softness', or non-binding content, of those norms that enabled coercion to achieve global compliance. Globally, the largely unilateral pressure exercised upon private sector agents - bypassing national jurisdictions and diplomatic routes - was a central element of the reorganisation of the global financial system that made it more transparent and accessible for law enforcement officials. Although consented, the various systems of regular monitoring and evaluation of domestic policies present in the international instruments were deliberately designed to shape national government policy and provoke legal and institutional change in domestic systems. Global legislative harmonisation in those fields, a still ongoing process, has structural sources and is thus relatively difficult to revert.

It is irrefutable, however, that from the standpoint of domestic anticorruption and money laundering law enforcement officials in Brazil those global regimes offered an excellent opportunity to work more effectively. The still ongoing appropriation and adaptation of international norms and institutional practices by public servants has been central to their internationalisation through the 
various paths described above. Although external coercion does take places, it is still the internal activism of parts of the bureaucracy, using international norms, that promoted institutional change. This was a central element of the transformation in the relationship between Brazilian state institutions and its own higher ranks of power.

International relations were at the core of one of the principal transformations in the Brazilian state and society observed in the last two decades. While anticorruption has not at all been a priority for Brazil's foreign policy, the dense intergovernmental networks and fundamental inter-societal interaction with other states was sufficient to elevate this issue within the broader policy agenda. Albeit quietly, this agenda evolves internationally and in Brazil. International cooperation continues to be broadened and deepened and the transnational enforcement of anticorruption law is a global trend. The increased transparency in financial systems as well as new international agreements are beginning to more seriously affect tax evaders and influence national taxation policies.

The developments described above indicate that it is impossible to tell the story of Brazil's anticorruption policy and politics without reference to international relations and the global governance of corruption and money laundering. This article intended to advance this debate.

\section{References}

Abbott, K. W., and D. Snidal. "Filling in the folk theorem: The role of gradualism and legalization in international cooperation to combat corruption." Paper presented at the American Political Science Association Meetings, Boston, Massachusetts, August 30, 2002. Acharya, A. "How Ideas Spread: Whose Norms Matter? Norm Localization and Institutional Change in Asian Regionalism.” International Organization 58, no. 2 (2004): 239-75. doi: https://doi.org/10.1017/S0020818304582024.

Andreas, P., and E. A. Nadelmann. Policing the globe: criminalization and crime control in international relations. Oxford: Oxford University Press, 2006.

Araujo, F. D. "Análise temática da estratégia nacional contra a corrupção e a lavagem de dinheiro (ENCCLA).” Revista Brasileira de Politicas Públicas 2, no. 1 (2012): 53-82. http://dx.doi.org/10.5102/rbpp.v2i1.1649.

Avant, D. D., M. Finnemore, and S. K. Sell, eds. (2010). Who governs the globe? Cambridge; New York: Cambridge University Press.

BBC-Brasil. 2017. "Ex-presidente do Peru tem prisão decretada; Lava Jato avança no exterior e põe governos da América Latina sob suspeita.” BBC, February 10, 2017. Acessed January 22, 2018. http://www.bbc.com/portuguese/brasil-38907251

Benites, A. 2017. "Procuradores de 15 países se unem em investigação sobre construtora Odebrecht.” El Pais, February 16, 2017. Acessed January 22, 2018. https://brasil.elpais. $\mathrm{com} /$ brasil/2017/02/15/politica/1487174435_593255.html 
Biersteker, T. J., and S. E. Eckert, eds. Countering the financing of terrorism. [London]: Routledge, 2007.

Brasil. "Decreto no. 3.678, de 30 de novembro de 2000. Promulga a Convenção sobre o Combate da Corrupção de Funcionários Públicos Estrangeiros em Transaçôes Comerciais Internacionais, concluída em Paris, em 17 de dezembro de 1997.” Diário Oficial da União, December 1, 2000. http://www.planalto.gov.br/ccivil_03/decreto/d3678.htm Brasil. "Decreto no. 5.015, de 12 de março de 2004. Promulga a Convenção das Naçóes Unidas contra o Crime Organizado Transnacional." Diário Oficial da União, March 15, 2004. http://www.planalto.gov.br/ccivil_03/_ato2004-2006/2004/decreto/d5015.htm Brasil. "Decreto no. 5.687, de 31 de janeiro de 2006. Promulga a Convenção das Nações Unidas contra a Corrupção, adotada pela Assembléia-Geral das Nações Unidas em 31 de outubro de 2003 e assinada pelo Brasil em 9 de dezembro de 2003.” Diário Oficial da União, February 1, 2006. http:/www.planalto.gov.br/ccivil_03/_ato2004-2006/2006/decreto/d5687.htm

Bukovansky, M. "The hollowness of anti-corruption discourse." Review of International Political Economy 13, no. 2 (2006): 181-209.

David-Barrett, E. "Are some bribes more harmful than others? Exploring the ethics behind anti-bribery laws." Journal of Interdisciplinary Economics 26, no. 1-2 (2014): 119-44. doi: https://doi.org/10.1177/0260107914540830.

David-Barrett, E., and K. Okamura. "The transparency paradox: why do corrupt countries join EITI?.” ERCAS Working Paper, no. 38 (2013). http://www.againstcorruption.eu/ publications/transparency-paradox-corrupt-countries-join-eiti/

DiBianco, G., and W. E. Pearson. "Anti-Corruption Due Diligence in Corporate Transactions: How Much is Enough?” Review of Securities \& Commodities Regulation 41, no. 11 (2008): 125-32.

Finnemore, M., and K. Sikkink. "International Norm Dynamics and Political Change." International Organization 52, no. 4 (1998): 887-917. doi: https://doi.org/10.1162/002081898550789

George, B. C., K. A. Lacey, and J. Birmele. "The 1998 OECD Convention: An impetus for worldwide changes in attitudes toward corruption in business transactions." American Business Law Journal 37, no. 3 (2000): 485-525. doi: https://doi.org/10.1111/j.1744-1714.2000.tb00276.x

Giacomet Junior, I. A., and A. J. A. Silveira. "Desempenho da cooperação jurídica internacional nos três anos de "lava jato"." Consultor Jurídico, March 28, 2017. Accessed January 22, 2018. https://www.conjur.com.br/2017-mar-28/desempenho-cooperacaojuridica-internacional-lava-jato

Guerzovich, F. Effectiveness of International Anticorruption Conventions on Domestic Policy Changes in Latin America. [n.p.]: Open Societzy Foundations, 2011.

Heimann, F. F. "Combatting international corruption: the role of the business community." In Corruption and the global economy edited by K. A. Elliott, 147-161. [Washington, DC]: Peterson Institute, 1997. 
Huntington, S. P. Political order in changing societies. [n.p.]:Yale University Press, 2006. Hurrell, A. "International Law and the Changing Constitution of International Society." In The role of law in international politics essays in international relations and international law, edited by. M. Byers, 327-47. Oxford: Oxford University Press, 2010.

Kennedy, D. “The Internaitonal Anti-Corruption Campaign.” Connecticut Journal of International Law 14 (1999): 455-65.

Kerche, F. “O Ministério Público e a Constituinte de 1987/88.” In O sistema de Justiça, F. Kerche, 106-37. Rio de Janeiro: Centro Edelstein de Pesquisas Sociais, 2010. Köppel, J. The SWIFT Affair: Swiss Banking Secrecy and the Fight against Terrorist Financing. Geneva: Graduate Institute Publications, 2011. doi: https://doi.org/10.4000/books.iheid.225. Krisch, N. "The decay of consent: international law in an age of global public goods." American Journal of International Law 108, no. 1 (2014): 1-40. doi: https://doi.org/10.5305/amerjintelaw.108.1.0001

Manfroni, C. A., and R. S. Werksman, eds. The Inter-American Convention Against Corruption: Annotated with Commentary. [n.p.]: Lexington Books, 2003.

Marcussen, M. The Basel Committee as a Transnational Governance Network. In Democratic Network Governance in Europe, edited by M. Marcussen, J. Torfing, 214-31. London: Palgrave Macmillan, 2007.

Ministério Público Federal (MPF). "Ministérios Públicos firmam declaração de cooperação internacional contra a corrupção.” MPF, February 17 [2017]. Accesed January 22, 2018. http://www.mpf.mp.br/atuacao-tematica/sci/noticias/noticias-1-1/ministerios-publicosfirmam-declaracao-de-cooperacao-internacional-contra-a-corrupcao

Nance, M. T. "Naming and Shaming in Financial Regulation: Explaining Variation in the Financial Action Task Force on Money Laundering." In The politics of leverage in international relations: name, shame, and sanction, edited by H. R. Friman,. Basingstoke: Palgrave Macmillan, 2015.

Pontes, F. "Medidas anticorrupção não são invenção brasileira, diz Janot." Agência Brasil, December 07, 2016. Accessed January 22, 2018. http://agenciabrasil.ebc.com.br/ politica/noticia/2016-12/medidas-anticorrupcao-nao-sao-invencao-brasileira-diz-janot

Praça, S., and M. M. Taylor. "Inching Toward Accountability: The Evolution of Brazil's Anticorruption Institutions, 1985-2010." Latin American Politics and Society 56, no. 2 (2014): 27-48. doi: https://doi.org/10.1111/j.1548-2456.2014.00230.x

Rodiles, A. "The Design of UN Sanctions Through the Interplay with Informal Arrangements." Research Handbook on UN Sanctions and International Law. edited by L. V. Herik, 177-93. Cheltenham: Edward Elgar, 2017.

Rose, C. International anti-corruption norms: their creation and influence on domestic legal systems. Oxford, UK: Oxford University Press, 2015.

Sharman, J. C. The money laundry: Regulating criminal finance in the global economy. n.p.]: Cornell University Press, 2011. 
Sharman, J. C., and D. Chaikin. "Corruption and Anti-Money-Laundering Systems: Putting a Luxury Good to Work." Governance 22, no. 1 (2009): 27-45. doi: https://doi.org/10.1111/j.1468-0491.2008.01420.x.

Sidhu, K. "Anti-corruption compliance standards in the aftermath of the Siemens scandal." German Law Journal 10, no. 8 (2009): 1343-54.

Spahn, E. "Implementing Global Anti-Bribery Norms from the Foreign Corrupt Practices Act to the OECD Anti-Bribery Convention to the UN Convention Against Corruption." Indiana International and Comparative Law Review 23, no. 10 (2013): 1-34. doi: https://doi.org/10.18060/17871

Trotta, S. B., and L. V. Ferreira. "Cooperação jurídica internacional em matéria penal: contornos históricos." Sistema Penal \& Violência 5, no. 1 (2013): 1-14.

Vladimir Aras, "Rumo à Europa," Blog do Vlad, [n.p.], August 23, 2016, https:// vladimiraras.blog/2016/08/23/rumo-a-europa/

Wang, H., and J. N. Rosenau (2001). "Transparency international and corruption as an issue of global governance." Global Governance 7, no. 1 (2001): 25-49.

Windsor, D., and K. A. Getz. "Multilateral cooperation to combat corruption: Normative regimes despite mixed motives and diverse values." Cornell International Law Journal 33, no. 3 (2000): 731-72. 